\title{
Changes In Best Management Practices Monitoring And Enforcement And Their Impact On Forestry In West Virginia
}

William Mccormick

Follow this and additional works at: https://researchrepository.wvu.edu/etd

\section{Recommended Citation}

Mccormick, William, "Changes In Best Management Practices Monitoring And Enforcement And Their Impact On Forestry In West Virginia" (2018). Graduate Theses, Dissertations, and Problem Reports. 7291. https://researchrepository.wvu.edu/etd/7291

This Thesis is protected by copyright and/or related rights. It has been brought to you by the The Research Repository @ WVU with permission from the rights-holder(s). You are free to use this Thesis in any way that is permitted by the copyright and related rights legislation that applies to your use. For other uses you must obtain permission from the rights-holder(s) directly, unless additional rights are indicated by a Creative Commons license in the record and/ or on the work itself. This Thesis has been accepted for inclusion in WVU Graduate Theses, Dissertations, and Problem Reports collection by an authorized administrator of The Research Repository @ WVU. For more information, please contact researchrepository@mail.wvu.edu. 


\title{
CHANGES IN BEST MANAGEMENT PRACTICES MONITORING AND
} ENFORCEMENT AND THEIR IMPACT ON FORESTRY IN WEST VIRGINIA

\author{
William McCormick \\ Design \\ at West Virginia University \\ in partial fulfillment of the requirements \\ for the degree of
Master of Sciences
in
Forestry \\ Dr. Joseph McNeel, PhD, Committee Chair \\ Dr. David McGill, PhD \\ Dr. Michael Strager, PhD
}

Thesis submitted to the Davis College of Agriculture, Natural Resources, and

Division of Forestry and Natural Resources

\author{
Morgantown, West Virginia \\ 2018
}

Keywords: Forestry, Best Management Practices, Non-Point Source, Appalachia

Copyright 2018 William McCormick 
Abstract

\title{
Changes in Best Management Practices Monitoring and Enforcement and their Impact on Forestry in West Virginia
}

\author{
William McCormick
}

Forestry Best Management Practices are a compilation of environmental regulations established to help mitigate and offset water sedimentation and soil erosion. This study examines severe layoffs in the West Virginia Division of Forestry and the resulting cessation in BMP compliance inspections by the State of West Virginia. This study found a significant decline in notifications to the state from loggers about impending timber harvests, a decline of 14.5 percent from the average of the previous three years prior to the curtailment in inspections due to the layoffs, and significant declines in the proper establishment of forestry BMP criteria on notified timber harvests, a decline of 13 percent statewide from previous years in terms of sites passing their overall BMP inspections. Findings on non-notified harvested sites for forestry BMP compliance proved inconclusive. 


\section{Acknowledgements}

I would like to thank the staff of the West Virginia Division of Forestry and the West Virginia Department of Environmental Protection for their help and support. Special thanks to Jeremy McGill and David Turnipseed for their professionalism and assistance. 


\section{Table of Contents}

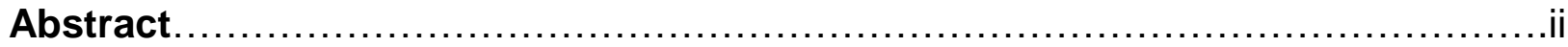

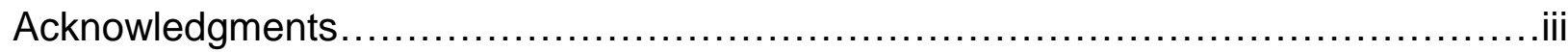

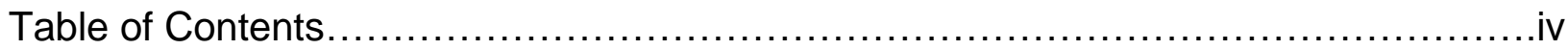

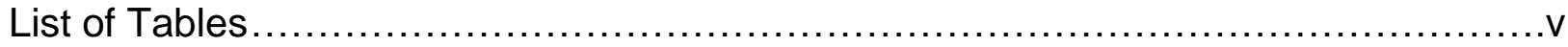

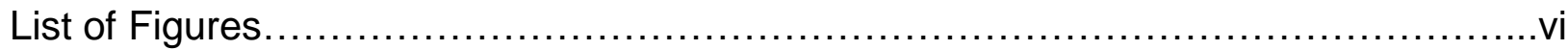

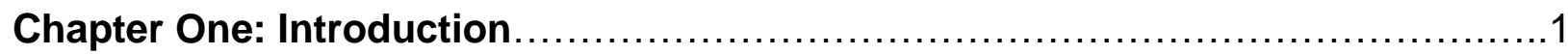

Chapter Two: Literature Review $\ldots \ldots \ldots \ldots \ldots \ldots \ldots \ldots \ldots \ldots \ldots \ldots \ldots \ldots \ldots \ldots \ldots \ldots \ldots$

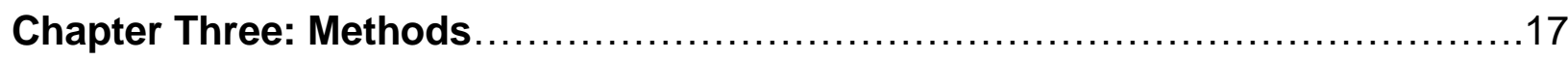

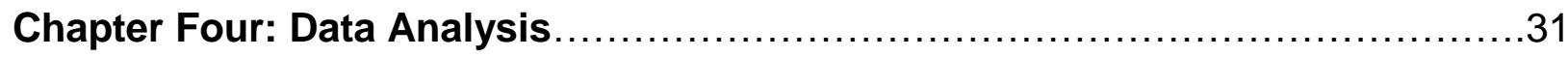








\section{List of Tables}

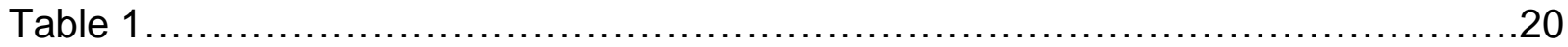

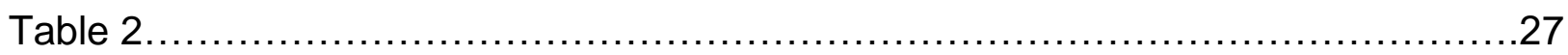

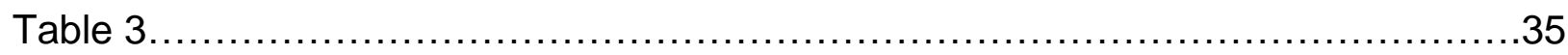

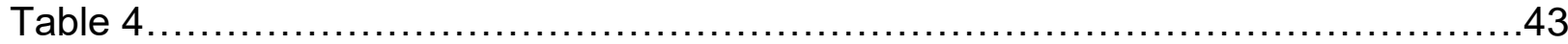




\section{List of Figures}



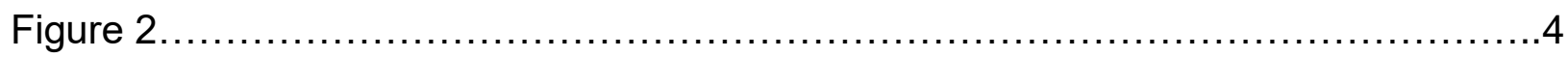

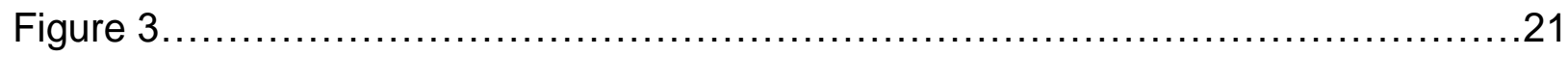

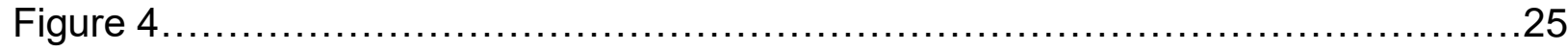

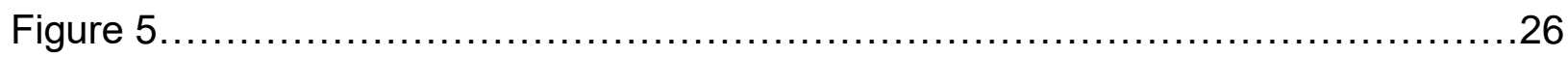

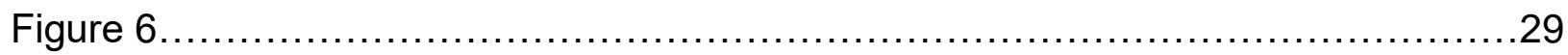

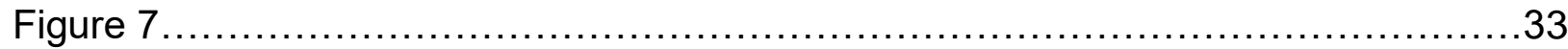

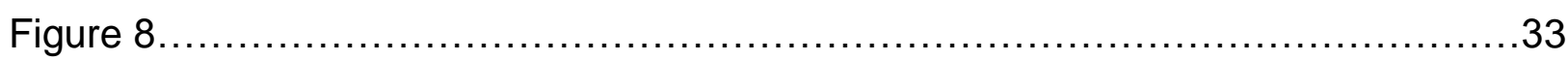

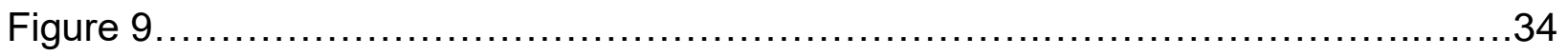






\section{Chapter One: Introduction}

\section{Background and Setting}

Forestry Best Management Practices (BMPs) are a common compilation of environmental regulations established to help mitigate and offset environmental pollution, water sedimentation, and soil erosion. In 1992, the West Virginia Legislature established BMP criteria as law, through the Logging Sediment Control Act (LSCA), intended to reduce stream sedimentation and soil erosion on harvested sites throughout the state. The LSCA states that "It is the policy of this state to strengthen and extend the present sediment control activities in the state by implementing operator licensing, logger certification, and logging operations notification programs."

The state agency charged with the responsibility for this legislation was the West Virginia Division of Forestry (WV DOF). The LSCA further states the legislative authorization for the WV DOF to require all logging operators in the state to become licensed, for all logging operations to be supervised by a logger certified in silvicultural BMPs, for all logging operators to notify WV DOF of all timber harvest establishment in the state, for all logging operators to follow WV DOF established guidelines, as well as authorizing WV DOF to enforce the establishment of forestry BMPs and timber harvesting notifications.

In their enforcement of the LSCA, the WV DOF established a logging operators training and licensing program, a logging notification database, compiled the WV Silvicultural Best Management Practices for Controlling Soil Erosion and Sedimentation 
from Logging Operators (2014), a pamphlet publication of the required forestry BMPs within the state, and established an inspection process on all notified timber harvests in the state, in which a WV DOF forester made on-site visits and inspections both during and at the completion of harvesting activities. This process was designed to be preventative in nature, in that the logger licensing and training program, as well as onsite inspections by WV DOF foresters, were meant to offer training and recommendations to loggers throughout the timber harvesting process to ensure proper establishment of forestry BMPs.

Forestry BMPs required by the WV DOF are intended to mitigate the potential for non-point source pollution, sediment and soil erosion, from entering adjacent streams and watersheds. The West Virginia Silvicultural Best Management Practices for Controlling Soil Erosion and Sedimentation from Logging Operators (2014), a publication published and maintained by the WV DOF, establishes a list and description of required forestry BMPs to be established after harvesting on all timber harvests within the state to achieve the goal of non-point source pollution mitigation.

These required BMPs include; streamside management zones (SMZs), road decommissioning, log landing placement, water bar and water diversion establishment, and stream crossing requirements. SMZs are areas of forest adjacent to perennial, ephemeral, and intermittent streams. An example from the West Virginia Division of Forestry Silvicultural Best Management Practices pamphlet of a streamside management zone is provided in Figure 1. WV DOF BMPs require loggers to maintain a minimum distance of 100 feet between any perennial/intermittent stream and any soil disturbance or erosion due to harvesting activities and this buffer zone is defined as an 
SMZ. This buffer is reduced to 25 feet for any ephemeral streams. Likewise, log landings must be established outside of SMZs, and any soil disturbance occurring inside an SMZ must be corrected following harvesting. Any logging debris such as tree tops should be minimized inside SMZs and all debris must be removed from these areas following harvesting.

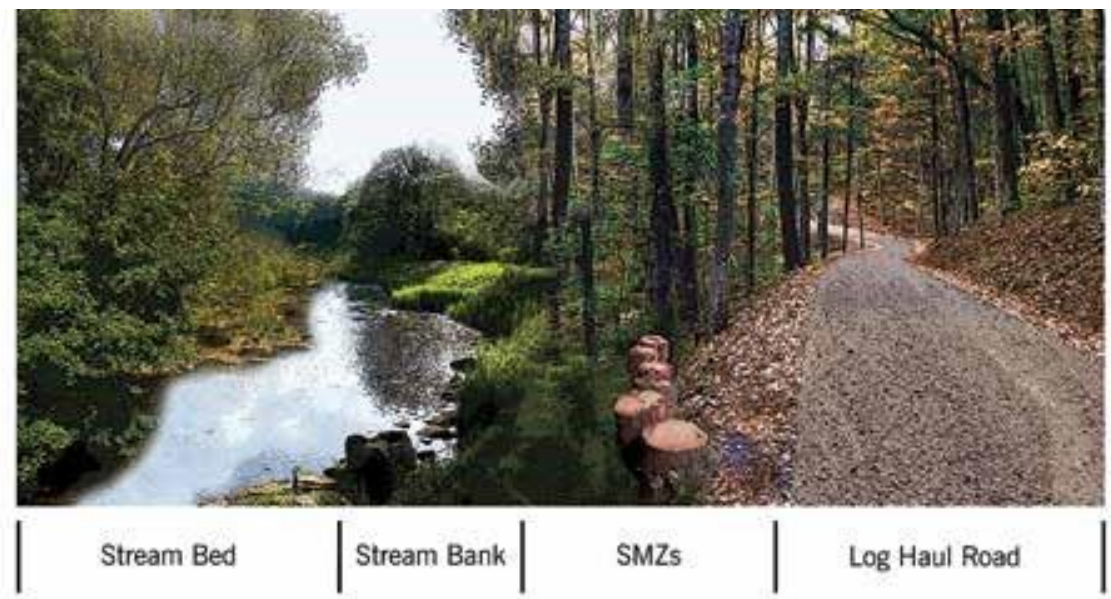

Figure 1. Streamside Management Zone (SMZ).

WV DOF BMPs further require loggers to decommission all haul and skid roads following harvesting, haul roads should be stabilized and left at a slope of 15 percent or less, skid roads should be stabilized and left at a slope of 20 percent or less. Stream crossings should be established using temporary bridges or culverts to minimize sedimentation entering streams during harvesting activities. Water bars are also required to be established on roads following harvesting to divert water off reclaimed roads and into the adjacent forest, preventing sediment runoff and failures in decommissioned roads. An example of a properly established water bar from the West Virginia Silvicultural Practices pamphlet is provided in Figure 2. These water bars are mounds of earth created on a regular spacing along the length of decommissioned 
roads at an angle that allows water to escape the road system and runoff into adjacent forest cover. These required forestry BMPs collectively serve to minimize any potential for stream sedimentation.

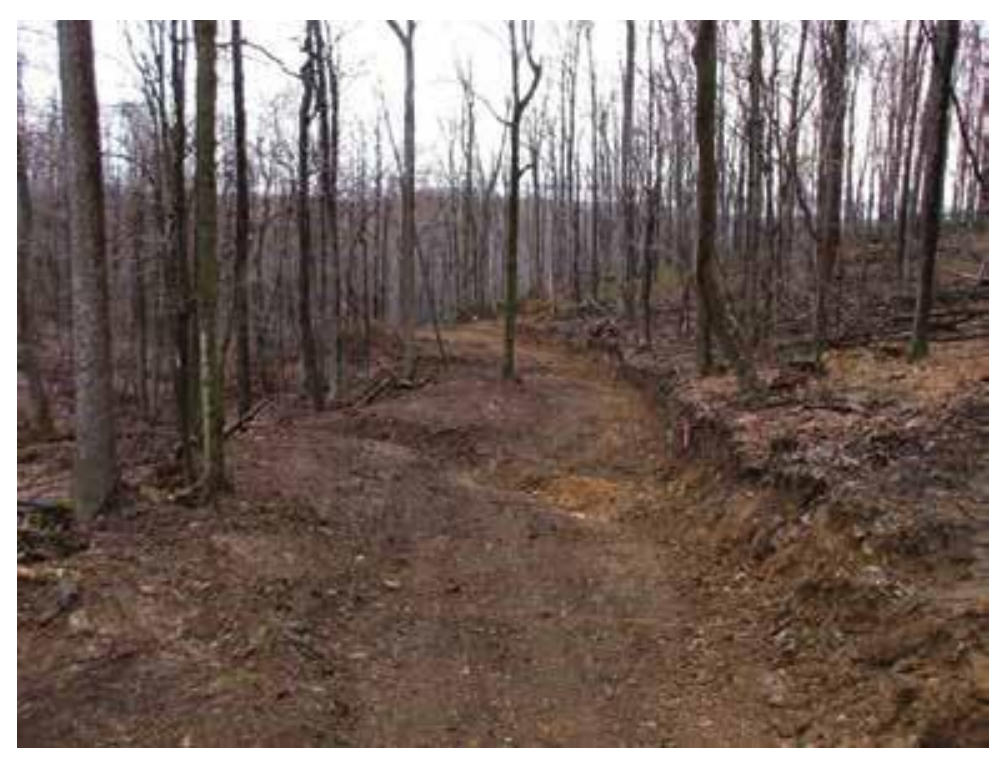

Figure 2. A typical water bar in place on a skid trail.

If WV DOF personnel determine that BMP establishment on site is inadequate, they are authorized under the LSCA to implement warnings and citations to the logging operator as well as order the logger to take specific actions to make BMP related corrections. This ensures that virtually all the notified timber harvests in the state have properly established forestry BMPs upon their completion.

In the summer of 2016, the WV DOF was forced to lay off 38 full-time employees and, because of these terminations, was forced to significantly curtail the inspection of active timber harvests for compliance with forestry Best Management Practices implementation across the state, with the exception of the logging operations in the 
eastern panhandle. In this part of the state, federal funding provided to support inspections in the Chesapeake Bay Watershed allowed inspections to continue.

Loggers were still required by the LSCA to make notifications to the WV DOF of any new timber harvests or the completion of active harvests. After the WV DOF stopped conducting regular BMP inspections, the only inspections of harvested sites within the state were conducted by the West Virginia Division of Environmental Protection (WV DEP). Unlike the WV DOF, WV DEP only dealt with compliance problems when either the WV DOF or WV DEP received a complaint about significant sedimentation problems or reports indicating the presence of excessive sedimentation in the stream under the authority of the WV Water Pollution Control Act (WVPCA).

WV DEP was not given additional funding or personnel to complete these inspections, nor did they at any point assume responsibility for enforcement of the LSCA. Anecdotal information about compliance issues, fines, and poor adherence to the BMP standards by some loggers also raised several questions about how this shift in responsibility might affect harvest-based BMP compliance over time (T. Koons, Personal Correspondence, October 11, 2017). 


\section{Purpose of Study}

The effectiveness of forestry Best Management Practices and logger compliance to BMPs have been heavily studied, both on a national level, as well as within West Virginia and the Appalachian region. However, this study offers a unique opportunity to quantify the effect of changes in the monitoring structure for logging Best Management Practices compliance by loggers harvesting forested properties in West Virginia after inspections by the WV DOF ended at the start of fiscal year (FY) 2017.

The purpose of this study is to quantify the effect of logging Best Management Practices compliance by loggers within the state of West Virginia after the cessation of inspections by the WV DOF. This study attempts to determine;

- Did timber notifications by loggers decline in a statistically significant manner over FY 2017 (July 1, 2016-June 30, 2017) relative to notification levels in previous years,

- Did the establishment and quality of BMP compliance measures on harvested sites across the state decline in any significant manner over FY 2017, and

- Were non-notified harvesting operations conducted in FY 2017 compliant with West Virginia BMP regulations?

Because these changes occurred within the last fiscal year of the implementation of this study, it is possible to directly compare certain factors associated with compliance in a "before and after" perspective relative to the type of monitoring process in place. Additionally, the population of loggers harvesting sites across the state can be 
subdivided, based on their continued compliance with the Logging Notification process that remained in place throughout the study period. This study explores whether loggers who adhere to the logger notification process are also still using Logging Best Management Practices during and after the harvest. Additionally, the study explores whether loggers who no longer comply with the logger notification requirements are also out of compliance with Logging Best Management Practices requirements for harvest operations they conducted after regular BMP inspections were halted in FY 2017.

Forestry Best Management Practices are an integral part of effective forest management, and their implementation is critical in the controlling of stream sediment erosion into waterways and watersheds. The implications of a breakdown in the establishment of forestry BMPs across the state are far reaching and long term relative to their potential impacts on the forests and watersheds within West Virginia.

This study attempts to shed light on recent events in relation to forestry BMP enforcement and establishment across the state and to quantify the impacts, if any, that this abrupt cessation in enforcement has had on the establishment of forestry BMPs on harvested sites within West Virginia. 


\section{Chapter Two: Literature Review}

\section{Forestry Best Management Practices}

To understand the impacts of forestry Best Management Practices enforcement, we first must understand the various practices that constitute forestry BMPs, and the context in which they were developed. There is a wide range and breadth of prior research and literature about the importance of BMPs, as well as the effect of BMP enforcement on water quality, sedimentation, and forest health.

Shepard (2005) summarized the history behind the rise of forestry BMPs and their use on the state level. His article suggested that the adoption of forestry BMPs evolved from the scientific realization that unregulated timber harvesting could affect the water quality of streams and watersheds. Shepard (2005) details that while the state of Oregon passed the very first forestry BMP program in 1971, it was the Federal Clean Water Act of 1972 (33 U.S.C. $§ 1251$ et seq) that prompted action on the part of the states.

The Federal Clean Water Act differentiates between point source pollution, defined as municipal sewage and waste treatment, or discharge from industrial facilities, and non-point source pollution which encompasses all agricultural and forestry practices. The development of non-point source pollution regulations spurred the introduction of forestry BMPs in several states to meet their obligations for agricultural and forestry related sedimentation pollution control. Section 208 of the 1972 Clean Water Act required states to develop programs to address non-point source water quality programs. 
In 1987, further amendments added section 319 (33 U.S.C. § 1329), which required states to identify their individual leading causes of non-point source water pollution and to develop specific programs to address these causes. Section 305(b) of the 1972 Clean Water Act further required the EPA to submit periodic reports to Congress summarizing information gathered by the states regarding water quality and pollution. According to the EPA National Water Quality Report to Congress (2004), silvicultural practices, including timber harvest operations, ranked $9^{\text {th }}$ nationally in 2004 relative to greatest sources of non-point source water pollution. With the passage of the 1972 Clean Water Act, and the subsequent 1987 Amendments, every single state, U.S. territory, and Native American tribe adopted some form of forestry BMP to address nonpoint source water pollution caused by timber harvesting.

Shepard (2005) further examines the development and implementation of forestry BMPs on the state level following the establishment of the Clean Water Act. His study reports that, while states have a wide latitude in the programs that they develop to enforce the requirements of the Clean Water Act, BMP regulations across the country typically cover topics such as; timber harvesting, site preparation, reforestation, stream crossings, riparian management zones, prescribed burning and fire lines, road construction and maintenance, pesticide and fertilizer uses, and wetlands. While state BMP programs are very similar, they are tailored specifically for the needs of their individual regions, so variations in prescription generally depend on the region, considering such factors as regional topography, weather, and terrain features.

The overall effectiveness of forestry BMPs in mitigating non-point source water pollution on harvested sites has been profound. In one study, Arthur et al. (1998) 
provided some of the first scientific research directly focused on forestry BMP implementation in the Southern Appalachian region, using test plots in eastern Kentucky, an area similar to parts of West Virginia regarding terrain, topography, and soil conditions. The study implemented two separate clear-cut harvests on the Robinson Research Forest in eastern Kentucky and applied forestry BMPs comparable to current forestry BMP standards in West Virginia on one of the two harvested sites, the other being a site that did not establish any forestry BMP practices.

The authors monitored the impacts of stream sedimentation and other values over the span of eight (8) years and compared the results between a timber harvest established with forestry BMPs, a timber harvest without forestry BMPs, and an uncut portion of the watershed (control site). They found that the site where BMP practices were implemented had a substantially lower rate of sedimentation discharge into the surrounding watershed over the span of time when compared to the site where no BMP standards were followed.

Looking at the effectiveness of BMP establishment in West Virginia, Kochenderfer et al. (1997) evaluated timber harvesting operations in northern West Virginia that used then current West Virginia BMP guidelines in their harvesting efforts. The authors found that the West Virginia BMP practices were effective in minimizing both soil erosion and water quality issues on the harvested watershed. They found that an efficiently developed harvesting road system combined with appropriate water control structures such as turnouts and water bars, minimizing roads, landings, and machinery in the appropriate riparian buffer area, as well as minimized and corrected soil disturbance and compaction on the logged area as detailed by West Virginia 
forestry BMP guidelines significantly reduced stream sedimentation into the watershed caused by harvesting activities.

\section{Forestry Best Management Practices Enforcement}

The overall development of BMPs and enforcement process varies from state to state. While the Clean Water Act requires action on the part of the states, they are given wide latitude in their development of appropriate BMPs, as well as in what capacity they enforce their BMP regulations. Blinn and Kilgore (2001) provide a summation of nationwide BMP practices and enforcement on a state level in a 2000 survey of all 50 state forestry agencies established policies regarding BMPs. Their work provided a summary and a comparison and contrast of BMP policies in 49 out of the 50 states. In their comparisons of similarities in BMPs they found an overall trend of the evolutionary nature of the science behind forestry BMPs as there was a strong trend for states to be continuously updating their BMP statutes over time in response to observed results.

Blinn and Kilgore (2001) further observed that the principle concern of all state BMP statutes and enforcement revolved around stream sedimentation and riparian buffer areas applied to timber harvesting. All 49 states had regulations in place for perennial streams, 40 had regulations in place for intermittent streams, 27 for lakes, 17 for domestic water supplies, and 11 for wetlands. The authors observed that while there was a wide range in terms of regional recommendations in BMPs nationwide, the three central themes shared between all state statues were a minimum riparian management zone, a minimum amount of required residual trees remaining following timber harvesting, and additional guidelines addressing management practices inside the riparian management zones. 
The National Association of State Foresters (NASF) maintains a constantly updated database of state forestry BMP regulations and enforcement strategies. The NASF differentiates state BMP statutes between regulatory/quasi-regulatory and voluntary. Regulatory/quasi-regulatory states have quantified their silvicultural non-point source regulations into law in some manner, with legally mandated state enforcement of BMP guidelines in some form. States with voluntary compliance systems encourage a wide range of BMP establishment, but are not supported by any specific legislation to require their enforcement. According to their database (National Association of State Foresters), 30 of the states maintain regulatory, or quasi-regulatory BMP statutes, whereas 20 states maintain an entirely voluntary system regarding BMPs and their establishment and enforcement on harvested areas. Most of the states with voluntary regulations are located in the midwest, or deep south. West Virginia and all states adjacent to it in the Appalachian region maintains regulatory BMP statutes.

Aust et al. (1996) provide an in depth look at the benefits and costs of BMP establishment and enforcement in the state of Virginia over time. Their research details a summation of the history of BMP enforcement within the state of Virginia. With the establishment of BMPs in 1972 within the state, this was initially a voluntary nonregulatory BMP program. Recommended forestry BMP practices were established by the state forestry agency, and disseminated to local loggers, contractors and private landowners, however there was no regulatory enforcement or inspection process along with these recommend changes in timber harvesting. The authors surmise that this was the general practice for all state forestry agencies in the southeast region prior to the 
1980s. The BMP program in this form has an establishment rate on timber harvests of 42 percent on the statewide level.

In 1987, with amendments to the Clean Water Act and the progression of scientific research into the positive impacts of BMPs on stream sedimentation and erosion, the Virginia Department of Forestry strengthened the language of their BMP guidelines and constructed an onsite compliance inspection process for timber harvests within the state involving onsite inspections both during and after harvesting had ended. A central priority of this tightening of BMP enforcement was increased extension and outreach with loggers and private landowners both demonstrating proper BMP establishment techniques, as well as their economic value to the industry. While Virginia had not at this point codified their BMP process in state regulatory statute and was thus still enacting a voluntary process, by 1992, proper BMP establishment rates had climbed to 92 percent across the state because of this transition to an onsite inspection process.

The final strengthening of the BMP enforcement process in Virginia came in regard to their transitioning from a voluntary model to a regulatory one. In 1993 Virginia enacted a sediment statute into state law, requiring a minimum performance standard, or "enforceable criteria" on all timber harvests within the state. This state legislation gave the Virginia Department of Forestry regulatory authority to issue fines or stop work orders for silvicultural non-point source pollution sources. This transition from a voluntary model to a regulatory one was designed to ensure compliance from a few "chronic non-compliers" within the state. 
Aust et al. (1996) also detailed a noticeable increase in water quality across the state of Virginia in all regions because of the transition from a voluntary to regulatory model of BMP enforcement. The authors calculated the relationship between the cost to the landowner of BMP establishment in relation to the increase in water quality that a more stringent BMP establishment program entailed. They noted that private landowners, and not the logger, bear the brunt of the cost of BMP establishment with few tangible financial benefits in return. This is in the form of a decrease in potential harvestable timber onsite, as well as a reduction in stumpage price from the logger to compensate his added costs in BMP establishment. However, their work also showed a substantial increase in water quality and control of silvicultural non-point source pollution as a result of the transition from a voluntary model with a compliance rate of 42 percent to a more stringent inspection based model with a compliance rate of 92 percent, and to a lesser extent with a transition to a regulatory model with an assumed compliance rate of 95 percent.

Wang et al. (2007) detailed the effectiveness over time of West Virginia's regulatory enforcement model of BMP establishment. According to their work West Virginia implemented forestry BMPs in the early 1970's along with most of other states nationwide. Since then, West Virginia has made five significant revisions to their BMP criteria, reflective of increasing scientific research and knowledge as well as long term observations in terms of effectiveness. This culminated in the passing of the LSCA in 1992 which transitioned West Virginia to a fully regulatory BMP model. Previous BMP compliance studies in West Virginia have shown a strong trend of increasing BMP compliance over time, with 59 percent compliance noted in 1981, increasing to 71 
percent in 1988, and 75 percent in 1991. There was a drop off in compliance rates in 1996 to 63 percent, associated with a change in the compliance checklist, adding many new BMPs or attributes that had not been previously sampled. Not taking into account these new samples, overall compliance remained generally static with past years. West Virginia's BMP compliance rates generally equivalent with other northeastern states.

Wang et al. (2007) studied the compliance rates in West Virginia given the passing of time since the last compliance study. In that time, three separate revisions had taken place in the state BMP guidelines, and the West Virginia Division of Forestry had been given new authority to issue BMP related citations to loggers. The authors made site visits to 116 randomly selected timber harvests located throughout the state. The levels of BMP establishment were quantified, and the site's landowners were interviewed. Their findings showed an overall BMP compliance rating of 74 percent across the state. There was a strong trend of increasing BMP compliance throughout the state over time as extension education and logger training continued through the West Virginia Division of Forestry, and as the BMP guidelines and enforcement system evolved with new scientific research and observed effectiveness. Most landowners were pleased with the BMP establishment process, with only 9 percent of private landowners reporting a negative experience with their loggers and the BMP process.

\section{Findings}

The amount of scientific literature available regarding forestry BMPs, their benefits, and the effectiveness of their enforcement both in the Appalachian region, as well as nationwide, is quite expansive. From the passing of the Federal Clean Water Act in 1972 and the establishment of the first state BMP education and voluntary 
enforcement programs, through today's contemporary regulatory programs, forestry BMPs have consistently shown to be effective in their mitigation of non-point source stream sedimentation.

Regulatory enforcement of forestry BMPs has also been shown to be very effective in achieving the goals of stream sedimentation mitigation, as well as improving overall forest health. The combination of state agency logger education and training, along with the ever-improving scientific understanding and implementation of forestry BMP regulations has led to significant gains in non-point source stream sedimentation mitigation, improved forest health, and the protection of landowner property.

West Virginia, as well as other states in the Appalachian region have a history of continual growth and success in the development of their state regulatory programs regarding BMPs, and the work that has been done to improve these programs has been invaluable in improving the overall health of the region's forests and streams. Whereas the topic of this thesis, and the events that have lead up to it regarding the cessation of forestry BMP regulatory enforcement in West Virginia are unprecedented, the wide breadth of scientific literature supports both the science behind the establishment and improvement of forestry BMPs, as well as the large successes of their regulatory enforcement in West Virginia, and nationwide. 


\section{Chapter Three: Methods}

\section{Purpose of Study}

The overall purpose of this study was to examine harvested sites in FY 2017 and evaluate whether the WV DOF layoffs had any impact on the extent of forestry BMP establishment and compliance.

To achieve this purpose, this research study seeks to answer the following questions:

- Did timber notifications by loggers decline in a statistically significant manner over FY 2017 relative to notification levels in previous years,

- Did the establishment and quality of BMP compliance measures on harvested sites across the state decline in any significant manner over FY 2017, and

- Were non-notified harvesting operations conducted in FY 2017 compliant with West Virginia BMP regulations?

At the outset of the design of this study, extensive interviews were conducted with relevant agency partners, the West Virginia Division of Forestry (WV DOF) and West Virginia Division of Environmental Protection (WV DEP). Interviews with Jeremy McGill, Assistant State Forester with WV DOF, elaborated on the WV DOF timber harvest notification process, the on-site BMP inspection process made by WV DOF personnel, and the corrective actions that WV DOF took on harvested sites that were out of compliance with WV DOF regulations (J. McGill, personal communication, July 2, 2017). 
Mr. McGill indicated that, prior to FY 2017, all loggers in the state of West Virginia were required to participate in a WV DOF training program and any timber harvest they engaged in was to be filed with the WV DOF. These notifications were stored in a WV DOF managed database, called the Logging Operation Notification, Inspection and Enforcement System (LONIE).

WV DOF has, since 1992, required that loggers provide the starting date(s), finishing date(s), size of harvested areas in acres, harvest site location(s), and other related information for all logging operations conducted in the state. Since January 1 , 2013 this data has been entered into the LONIE system by the WV DOF and subsequently used by WV DOF field personnel to complete their on-site inspections to determine BMP compliance on harvested sites. Any timber harvesting that occurred without first notifying the WV DOF was (and is) considered a "non-notified" harvest, and thus out of compliance with current Logging Sediment Control Act regulations. WV DOF personnel used (and still use) this system as the basis for BMP compliance (J. McGill, personal communication, July 2, 2017).

The LONIE database contains a list of all timber harvest notifications and relevant harvested site data reported to the WV DOF by year. This database was made available and used to obtain harvested site data for the study. 


\section{Study Design}

The research area for this study encompassed the entire state of West Virginia in terms of total reported timber harvest notifications in the LONIE database. However, the eastern panhandle region of the state was excluded from the study, since continued Federal funding to the WV DOF allowed timber harvest inspections to continue in this area throughout FY 2017. Logging notification data used for the study were also restricted to sites having a harvest start date and end date falling within FY 2017 (J. McGill, personal communication, July 2, 2017).

The WV DOF provided access and training in the use of the LONIE database for this research effort, which allowed access to the details for all timber harvest notifications within the state for the period of interest for this study. For the purposes of this study, only harvested site locations, harvesting beginning and ending dates, and size by acreage were accessed and recorded from the LONIE database.

While there was a brief period between the start of FY 2017 and the point at which layoffs occurred where enough WV DOF foresters were still employed and conducting timber harvest inspections, a large portion of properties harvested in FY 2017 went without any formal WV DOF inspection. For the purposes of this study, we did not delineate between the minority of harvested sites inspected by WV DOF personnel during this period and those sites that went without inspection (J. McGill, personal communication, July 2, 2017)

To determine if timber notifications by loggers declined in any significant manner over the 2017 fiscal year, an analysis was conducted by accessing records of notified 
timber harvests that fell within FY 2017 within the LONIE database. These notification records were compiled in Microsoft Excel and, for comparison purposes, this same analysis was conducted for harvested sites that fell within FY 2016, FY 2015, and FY 2014, respectively.

The harvest notification numbers detail the total amount of timber harvest notification received from loggers by the WV DOF on a fiscal year basis. The amount of harvest notifications received from loggers by the WV DOF for FY 2017 was compared with the amount of notifications received in fiscal years prior to the layoff.

To determine if the establishment and quality of BMP compliance measures on harvested sites across the state declined in any significant manner over the $2017 \mathrm{fiscal}$ year, actual site inspections were conducted on a defined number of sites harvested in FY 2017. The total number of notified timber harvests that fell within FY 2017 were identified, being restricted to harvest notifications that had a starting date in FY 2017 and an ending date in FY 2017, using the LONIE database (Table 1).

Table 1: Number of FY 2017 Timber Harvest Notifications, by WV DOF region, provided by LONIE.

\begin{tabular}{|lc|}
\hline WV DOF Region & $\begin{array}{c}\text { Number of Identified } \\
\text { Sites }\end{array}$ \\
\hline Region 1 & 281 \\
\hline Region 2 & 540 \\
\hline Region 3 & 156 \\
\hline Total & 977 \\
\hline
\end{tabular}


These notifications were grouped by WV DOF regions, because this grouping was used by WV DOF within the LONIE database at the time of this study (Fig. 3). A total of 977 observed entries were obtained and stratified by WV DOF region. These entries were then exported to a Microsoft Excel spreadsheet and further verified manually to ensure that they all met all of the testing criteria of the study.

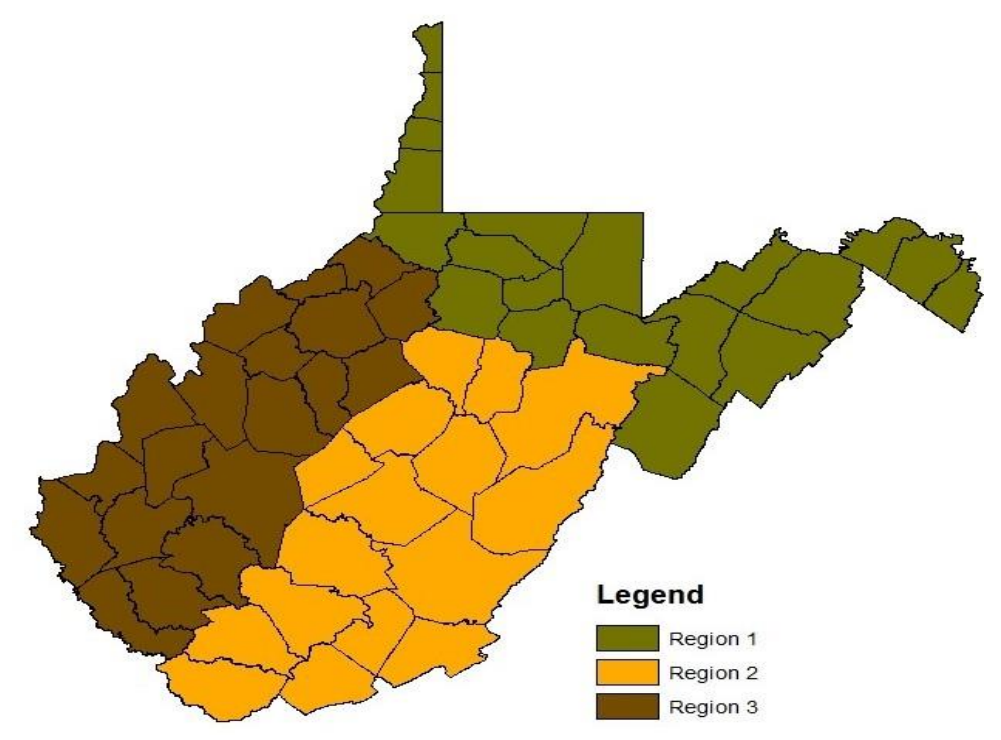

Figure 3. Map illustration of the three WV DOF Regions at time of the study.

Due to time and funding constraints placed on the study, not all of the 977 harvested sites could be visited and inspected. Harvested sites smaller than 40 acres in size were not considered for inspection for the sake of practicality in the field. As the 
sites were distributed across the state and grouped by WV DOF region, field inspections were made based upon the availability of sites selected for further study. Specifically, in certain areas of the state, all the identified harvest sites could be inspected based on location and amount of available time. In other areas, more sites were available for inspection than could actually be inspected, given the available time and funding constraints. In these instances, sites were selected based upon proximity and available time.

Each site was inspected using the criteria used during a WV DOF Final BMP compliance inspection. At the outset of the field data collection period, a small subset of these harvested sites was inspected by the researcher and an accompanying WV DOF forester to ensure that the inspection process followed WV DOF inspection standards.

On each of the inspected sites, two separate evaluations were made. The first was the determination of an overall passing or failing grade for each harvested site in terms of proper forestry BMP establishment. The second evaluation focused on defining an overall BMP quality rating based upon the amount of BMP work done on each of the harvested sites.

The overall pass/fail grade was an onsite determination made by the researcher relative to whether the harvested site met WV DOF BMP guidelines and if the harvested site posed an imminent water quality risk in terms of non-point source pollution. As the primary concern of all WV DOF onsite inspections is water quality risk through non-point source pollution, this can lead to situations where, even though a harvested site may actually meet established forestry BMP criteria, an immediate non-point source pollution issue exists that requires the harvested site to fail its inspection. 
Likewise, harvested sites can be lacking some required forestry BMP practices, yet have no immediate or potential long-term risk for non-point source pollution. Thus, the second evaluation was applied on harvested sites to better define the rate of establishment of individual forestry BMP requirements.

The overall BMP quality rating consisted of a scoring system, where each site was checked for compliance with specific WV DOF forestry BMP requirements, as defined in the WV Silvicultural Best Management Practices for Controlling Soil Erosion and Sedimentation from Logging Operators manual (WV DOF, 2014). Each site was scored based upon the number of established BMP criteria established on site versus the total number required for the site by the manual. BMP criteria used in this study were restricted to those that could be reasonably discerned onsite after the cessation of harvesting activities, rather than during harvest activities. The grading sheet developed specifically for the field-based inspections conducted for the study is illustrated below in Figure 4 .

Field data collection took place between May 2017 and August 2017. A total of 170 harvested were visited in the field data collection process, however 40 of these sites were disqualified as samples due to a variety of mitigating factors. The most common of these were that loggers had notified the state that harvesting was finished, however, in some cases, the logger actually returned and continued harvesting beyond the notified ending date.

Some timber harvests had been notified to the WV DOF, but for one reason or another were never actually harvested. On other sites, landowners submitted timber harvest notifications, but were self-logging their property or clearing forest land for 
agriculture. In practice these sorts of operations were notified to the WV DOF, and the inspecting WV DOF forester updated the database accordingly, however without oversight from in the field foresters, these issues remained unaccounted for and were thus disqualified from the study. 
WV Forestry BMP Grading Sheet

\section{Sample \#:}

Location:

Region:

Pass Fail

\section{Notified?}

\section{Streamside Management Zones}

100 feet SMZ Buffer from Perennial/Intermittent Streams?

25 feet SMZ Buffer from Ephemeral Streams?

Equipment operations minimized inside SMZ? Disturbed soil reclaimed? Log Landing located outside SMZ?

Log Landing located outside SMZ? If located inside SMZ properly reclaimed?

Haul Roads located outside SMZ? Skid roads minimized in SMZ? Fill slopes, if any, properly reclaimed?

\section{Logging Debris and Tops}

Haul roads left at 15 percent slope or less? Last 200 foot of Haul Roads graveled? Haul Roads do not pose a risk to water quality?

Skid Roads left at 20 percent slope or less? Skid Roads do not pose any risk to water quality?

Stream crossings established? (Culverts, drains, bridges, etc.)

All roads properly stabilized? (Haul roads above 10 percent and Skid Roads above 15 percent slopes respectively)

Log Landings properly reclaimed?

All landings/soil disturbed inside SMZ/any road exceeding 20 percent slope seeded?

All tops and debris pulled from perennial and intermittent streams?

Figure 4: Sample Grading Sheet used to record BMP compliance details for each site subjected to a field-based inspection during the study. 
A total of 130 harvested sites distributed across West Virginia, excluding the eastern panhandle, were identified for inspection for the study. The location of these harvested sites are provided, by WV DOF region, in Figure 5, while the numbers are summarized in Table 2. The researcher inspected each of these sites and applied the previously mentioned testing criteria to each site.

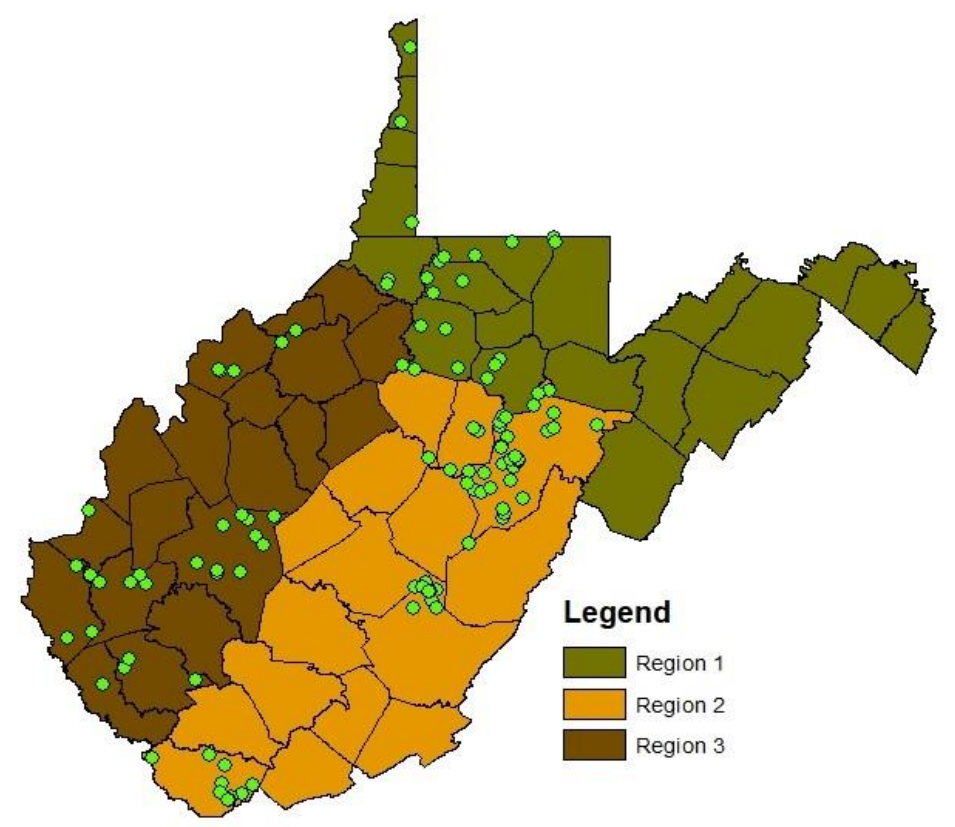

Figure 5: Distribution of the 130 researcher-inspected notified harvested sites. 
Table 2: Number of field-based harvest inspections, by WV DOF region, conducted during the study.

\begin{tabular}{|cc|}
\hline WV DOF Region & $\begin{array}{c}\text { Harvest Inspections } \\
\text { Conducted }\end{array}$ \\
\hline Region 1 & 40 \\
\hline Region 2 & 60 \\
\hline Region 3 & 30 \\
\hline Total & $\mathbf{1 3 0}$ \\
\hline
\end{tabular}

Statistical analysis of the sample population of notified timber harvests in relation to the total number of notified timber harvests available for inspection was performed to estimate sample size and power analysis using the Design of Experiment (DOE) platform of JMP software (JMP®, Version Pro 12.2, SAS Institute Inc., Cary, NC, Copyright (@2015). This analysis used a hypothesized, or null proportion, of 0.01 and assumed as the null hypothesis for the second research question that the stoppage of inspections by WV DOF would have no impact on the proper establishment of required forestry BMPs, and that due to the corrective nature of the WV DOF inspection process, notified timber harvests have an effective compliance rate of over 99 percent under normal circumstances.

This analysis used 0.015 as the predicted, or measured, value in the analysis. This value was chosen because preliminary results from field data collection efforts before the performance of the data analysis suggested that the proportion of total 
harvested sites sampled in non-compliance was approximately 15 percent of the total population of researcher inspected harvested sites. This analysis applied a one-sided Exact Agresti-Coull method.

From the power curve generated from this analysis, it was determined that, to obtain at least a 90 percent power for the test, about 25 samples should be collected from each region (Fig. 6). Of the three Regions, Region 3 was the smallest of the three in terms of the total population of harvested sites, and contained a sample size of 30 , which represented 19 percent of the sample population. For Regions 1 and 2 which were significantly larger in size and containing a larger number of possible samples, the decision of sample size was based upon having at least 10 percent of the total sample population represented; 14 percent of the population for Region 1 was sampled and 11 percent of the population for Region 2 was sampled.

Once field sites were inspected and the proportion of sites out of compliance for each region was estimated, the exact power of the test for each region was calculated using the same method. Thus, the calculated power of the test was 98 percent for Region 1, 97 percent for Region 2, and 97 percent for Region 3 (I. Holaskova, personal correspondence, Feb. 7, 2018).

Testing the third question of the study in relation to non-notified timber harvests proved to be problematic in the field. During the study, extensive interviews were conducted with WV DOF representatives to determine how to actually identify possible non-notified timber harvests that occurred during FY 2017 and understand how the WV DOF has dealt with non-notified timber harvests in the past. 


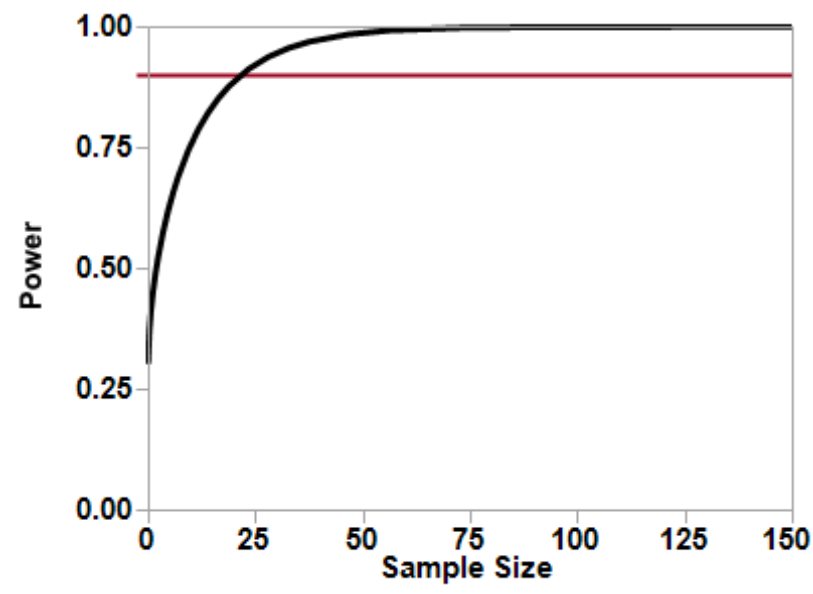

Figure 6. Statistical power curve for determining sample size for the three Regions.

According to WV DOF Forester, David Turnipseed, non-notification of timber harvests was an issue prior to the FY 2017 layoffs. The method of enforcement by the WV DOF to minimize logging outside of the compliance of the Logging Sediment Control Act is actually a somewhat random process where WV DOF Foresters come across these non-notified timber harvests during their normal work. Thus, inspection only occurs when WV DOF foresters actually find these non-notified timber harvests and get the chance to work with the respective loggers to bring them into compliance. However, with the layoff of 38 employees, actually locating non-notified sites was almost impossible (D. Turnipseed, personal communication, Aug. 7, 2017).

The third component of the study required the identification of a sample population of non-notified harvesting operations conducted in FY 2017 in the three WV DOF regions being evaluated (Regions 1, 2, and 3) and, after sites were identified, conduct inspections for BMP compliance. At the outset of the study, geospatial methods were considered as a means of identifying harvest based changes in forest canopy cover from FY 2016 to FY 2017 and help identify non-notified harvests. This approach 
proved to be impractical, as there was no definitive way to differentiate between timber harvesting, mining, commercial or agricultural land development, etc.

However, a small population of non-notified timber harvests were identified through the assistance of WV DOF foresters. Specifically, several non-notified harvested sites were discovered by a WV DOF forester working in Region 3 during his regular job duties.

These non-notified harvest sites were inspected using the same inspection methods used when inspecting notified harvested sites. Assistance with these inspections was provided by the WV DOF forester who had originally located the sites in the field. The number and distribution of non-notified harvest sites, a total of ten samples, were too closely distributed to be statistically significant. Due to the difficulty of identifying enough non-notified harvest sites, as well as time and budget constraints, efforts to identify and evaluate BMP compliance on non-notified timber harvest sites in a statistically meaningful manner were abandoned at the end of the field data collection period. 


\section{Chapter Four: Data Analysis}

\section{$\underline{\text { Research Question }}$}

This study addressed three questions regarding the impact of the WV DOF layoffs and the resulting cessation of BMP compliance inspections normally conducted by WV DOF personnel. Specifically, 1) was there any significant decline in timber harvest notifications during FY 2017 when compared against previous fiscal years notification levels; 2) did the establishment and quality of forestry BMP compliance measures on harvested sites across the state decline in any significant manner when these inspections ended; and 3) what is the level of BMP compliance on non-notified timber harvests within the state.

\section{Timber Harvest Notifications}

For each fiscal year, the total number of timber harvest notifications were queried within the WV DOF LONIE database. This query was restricted to timber harvests that began and ended within their respective fiscal year. These notifications were recorded as the total amount for each fiscal year between FY 2014-FY 2017 (Fig. 7). Timber Harvest Notifications received by WV DOF within the study criteria during FY 2017 fell by 237 from the previous year and were 14.5 percent lower than the average of the previous three fiscal years. Statistical analysis using a z-test for statistical significance suggested that there is enough evidence to demonstrate that the number of notifications were higher in the fiscal years prior to FY 2017 (I. Holaskova, personal correspondence, June 21, 2018). 
A second analysis was conducted using the same methods to test the number of timber harvest notifications received exclusively in the eastern panhandle region where timber harvest inspections did not cease. Timber harvest notifications received by the WV DOF within the eastern panhandle during FY 2017 fell by 16 from the previous year and were 10.1 percent lower than the average of the previous three fiscal years (Fig. 8).

A statistical analysis to test for differences in the reduction in notifications statewide and those observed in the eastern panhandle was conducted using an z-test. The test did not note any statistically significant differences between the two sample sets, suggesting that there was no statistically significant difference between the reduction in notifications statewide and those observed in the eastern panhandle. However, there was found to be only a 4.4 percent difference between the decline in timber harvest notifications received statewide, and the decline in timber harvest notifications exclusively in the eastern panhandle (I. Holaskova, personal correspondence, July 6, 2018).

\section{$\underline{\text { Notified Timber Harvests }}$}

The total number of harvested sites inspected in the study by WV DOF is summarized in Table 2. Upon the successful inspection of each harvested site during the field data collection period, each site was given an overall pass/fail rating and a scored checklist of forestry BMP criteria. Summaries of the pass/fail ratings and the scores for each region are illustrated in Figures 9 and 10. 


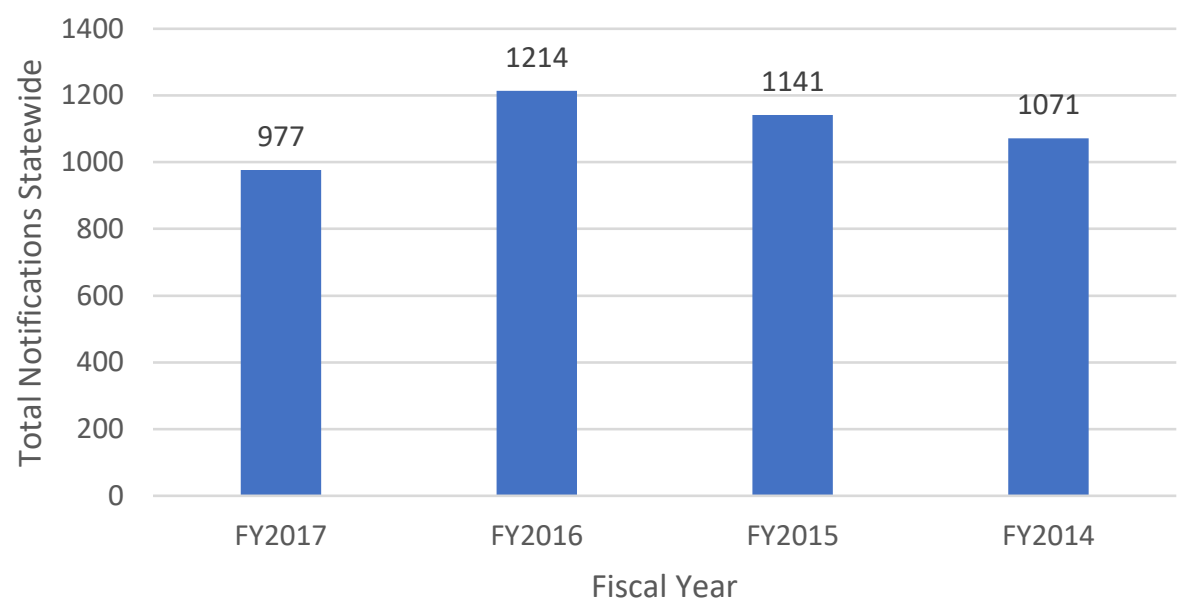

Figure 7. Total timber harvest notifications by fiscal year for the study area.

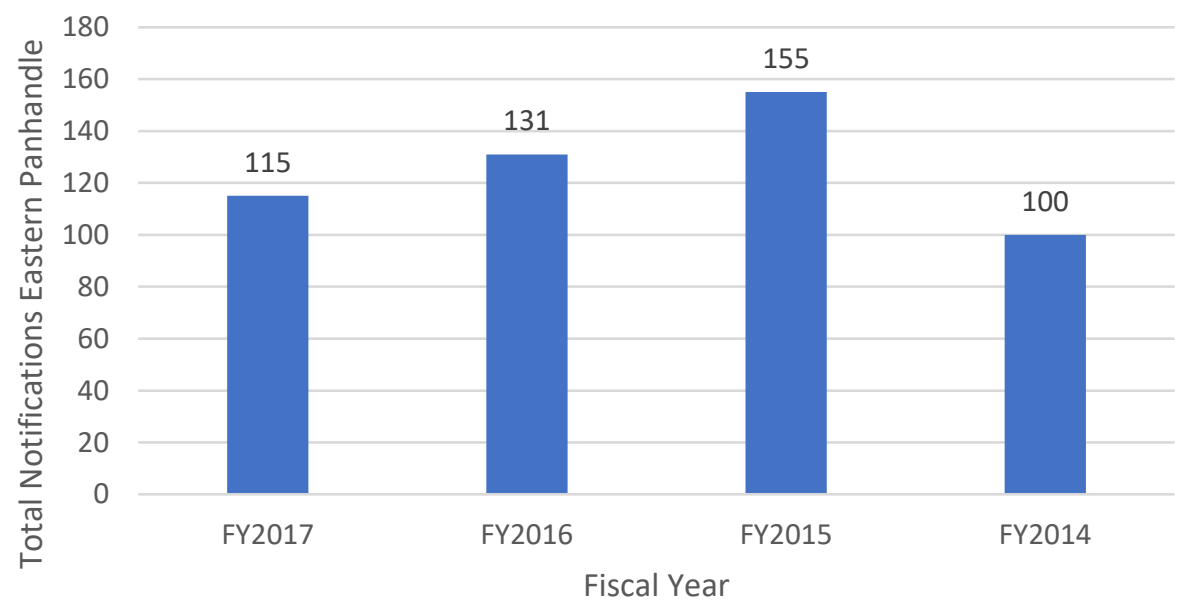

Figure 8. Total timber harvest notifications for the eastern panhandle by fiscal year.

The study determined that, for Region 1, a total of 34 harvested sites had passed inspection, representing 85 percent of the total population of samples. Overall average for forestry BMP establishment was 85 percent. For Region 2, a total of 54 harvested sites passed inspection, representing 90 percent of the total sample population. Overall 
BMP establishment for Region 2 averaged 90 percent. For Region 3, a total of 25 harvested sites passed inspection, representing 83 percent of the total sample population. Overall BMP establishment for Region 3 was 88 percent.

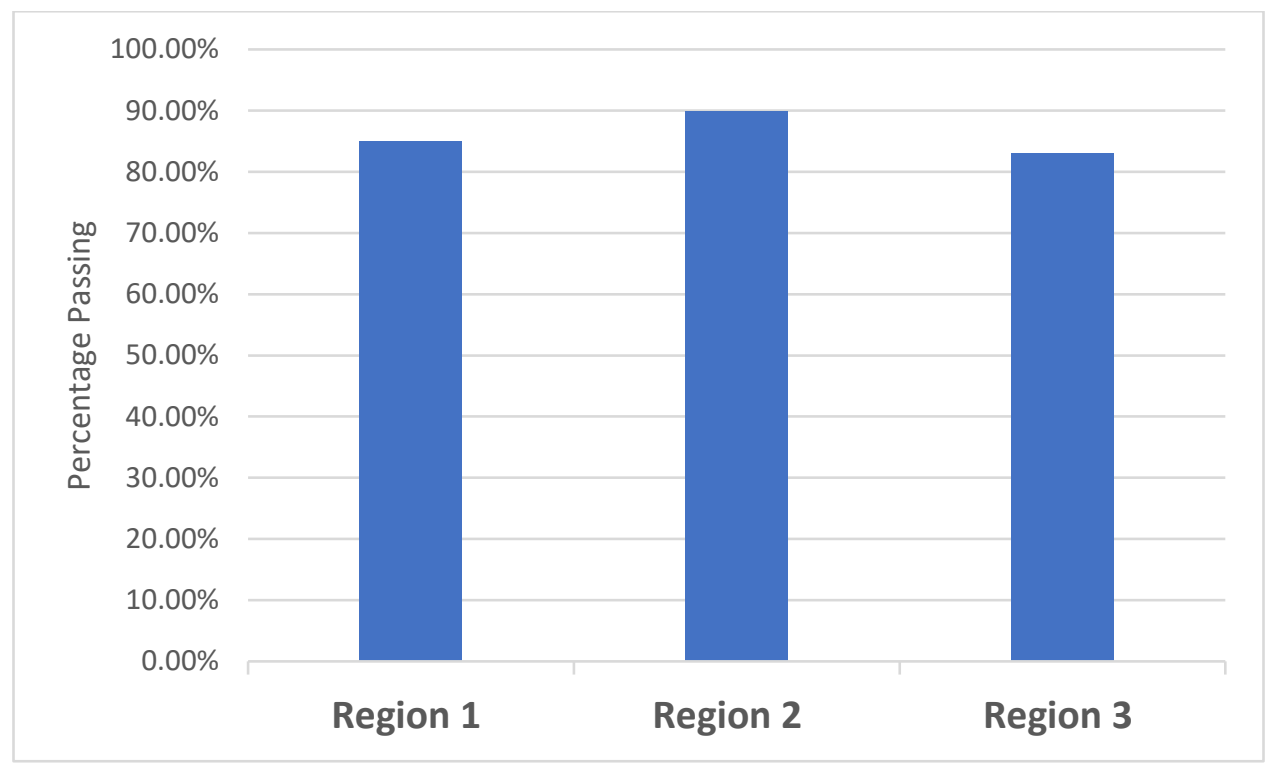

Figure 9. Total harvest inspection Pass/Fail rate by WV DOF Region.

Because of the corrective nature of the WV DOF timber harvest inspection process, this study assumed a compliance rate on harvested sites of greater than 99 percent prior to the layoff period in FY 2017. According to Assistant State Forester, Jeremy McGill, prior to the layoff period, WV DOF recorded an average initial BMP compliance rate of 95 percent on harvested site inspections. However, any sites found to be out of compliance were corrected via normal WV DOF practices and thus ensured that virtually all notified timber harvests within the state were compliant with existing BMP standards (J. McGill, personal communication, July 2, 2017). 


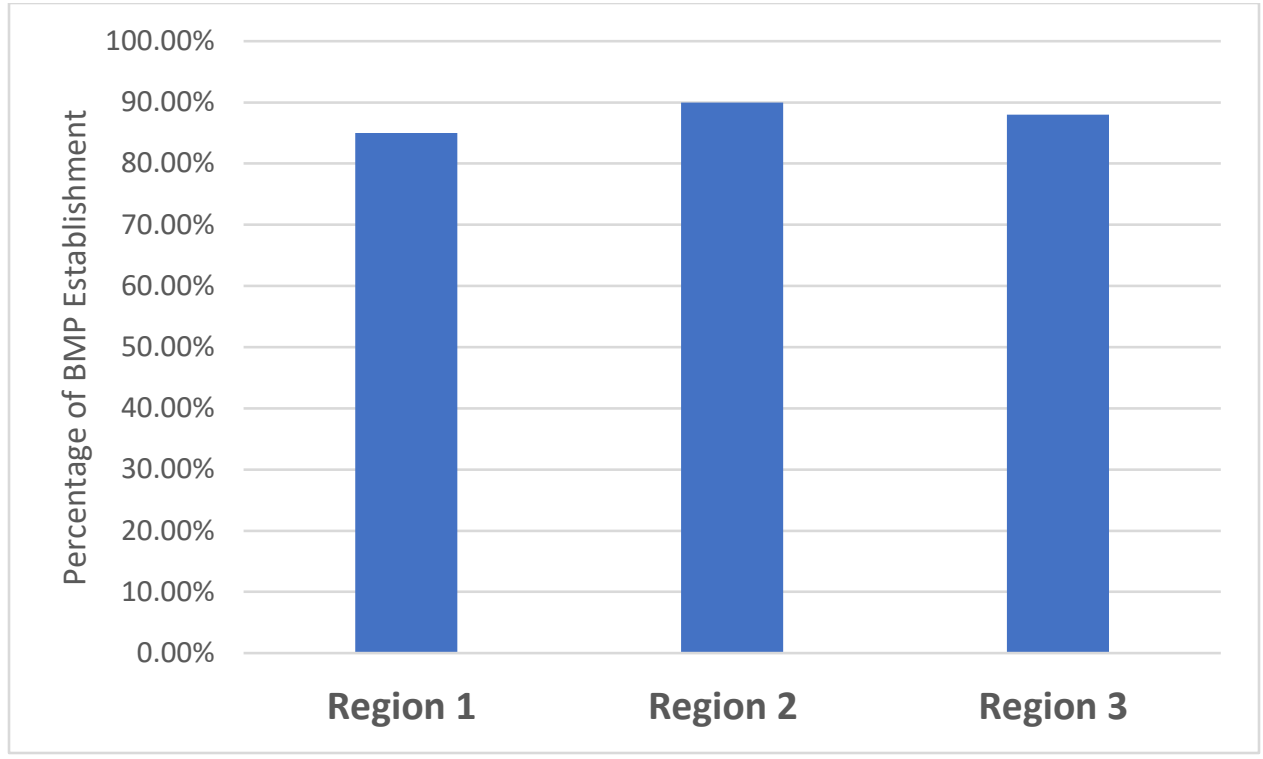

Figure 10. Total harvest inspection quality rate by WV DOF region.

Table 3 compiles the five most common BMP criteria, by category, found to be missing on notified timber harvests inspected during this study, by number of sites missing each criteria. For all regions, missing criteria related to streamside management zones were found to be the most common BMP issue, with 21 inspected sites missing criteria related to streamside management zones in total. Road decommissioning, water bars, and tops and debris removal each had 15 harvested sites found to be missing these criteria in total. Twelve harvested sites were found to be missing BMP criteria related to stream crossings in total.

Table 3. Summary of BMP issues for surveyed sites by WV DOF Region and for the entire study area.

\begin{tabular}{|c|c|c|c|c|}
\hline BMP Criteria & Region 1 & Region 2 & Region 3 & Total Sites \\
\hline Streamside Management Zones & 9 & 7 & 5 & 21 \\
\hline Road Decommissioning & 6 & 4 & 5 & 15 \\
\hline Stream Crossings & 5 & 3 & 4 & 12 \\
\hline Water Bars/Diversions & 5 & 5 & 5 & 15 \\
\hline Tops and Debris Removed from Streams & 6 & 4 & 5 & 15 \\
\hline
\end{tabular}


$\underline{\text { Non-notified Timber Harvests }}$

Due to difficulties in the identification and inspection of non-notified harvested sites, the small sample population of these sites was not considered large enough to be statistically significant. A total of ten (10) non-notified harvest sites were identified and inspected, however, they were all closely distributed within one WV DOF region and thus cannot be considered representative of the total population of non-notified harvested areas across the state.

For these ten non-notified harvested sites, four harvested sites passed the inspection for BMP compliance representing 40 percent of the total sample, and the overall BMP establishment was 42 percent. Again, these analysis results should not be considered representative of the overall compliance levels for non-notified harvest sites. However, the low compliance levels for these sample do imply that, in general, one could expect non-notified harvest sites to have few implemented BMP standards on site and that these sites probably produce significantly more stream sedimentation in the state than sites where notification requirements have been met. 


\section{Chapter Five: Discussion and Conclusion}

\section{$\underline{\text { Timber Harvest Notifications }}$}

This study showed a decline in the total number of timber harvest notifications received by the WV DOF during FY 2017. Timber Harvest notifications within the study criteria fell by 237 during FY 2017, from 1214 to 977, and decreased, on average, about 14.5 percent when compared to the previous three fiscal years (2014-2016).

The decline in the number of notifications began after 38 WV DOF employees were laid off at the beginning of the 2017 fiscal year (July 1, 2016). This sudden loss of foresters across the state severely limited the ability of the WV DOF to adequately enforce required forestry BMP standards on harvested sites. The decline in the number of timber harvest notifications did not seem to result from reduced harvesting in West Virginia, but rather because loggers across the state realized that regulatory efforts relative to BMP compliance were generally non-existent because of the layoffs.

We believe, based on the results of this study that the observed reduction in harvest notifications were directly correlated to the loss of these 38 WV DOF employees and subsequent issues with harvesting best management compliance on sites harvested throughout the FY 2017 period. Without the presence of field-based WV DOF

personnel conducting regular BMP compliance inspections, public awareness of forestry BMP regulations can be expected to decrease. Furthermore, without the enforcement process in place, there will be no real incentive on the part of loggers to notify the WV DOF or to comply with BMP standards on tracts they harvest. 
The potential decline in notifications and BMP compliance on harvested sites can be expected to increase over time without some type of response by the state. To mitigate these issues, WV DOF should revamp their regulatory process to account for the smaller number of foresters available to conduct BMP compliance inspections.

\section{$\underline{\text { Notified Timber Harvests }}$}

This study noted a significant decline in BMP compliance on notified timber harvests across much of the state. Inspections to determine BMP compliance on selected sites that were harvested in FY 2017 suggest that sites across the state would pass a standard BMP inspection approximately 85 percent for Region 1; 90 percent for Region 2; and 83 percent of the time for Region 3. In contrast, prior to the FY 2017 layoffs, a compliance rate of over 99 percent was estimated for harvested sites across the state, based on comments made by Jeremy McGill (J. McGill, personal communication, July 2, 2017).

A second set of measures were used during this study to quantify the extent to which BMP compliance work was established on an inspected site. During the inspection process, some harvested sites lacking required BMP work still passed the BMP compliance inspection because there was no perceived imminent non-point source pollution risk, while other sites with properly developed BMP criteria in place failed because of a perceived imminent non-point source pollution risk. This measurement process provided an actual scoring structure and produced an additional data set that yielded a more well-rounded perspective of total BMP establishment on inspected sites (see Table 3, pg. 34). 
The scoring suggested that a significant decline occurred in terms of the overall establishment of required forestry BMP criteria on harvested sites in FY 2017. Region 1 was found to have an 85 percent overall BMP establishment rate, while Region 2 had a 90 percent establishment rate, and Region 3 had an 88 percent establishment rate.

This approximately mirrors the total passing rate for inspection on harvested sites by region. Common occurrences of missing BMP criteria on certain sites included; lack of water bar establishment; lack of streamside management zone buffers; and failure to remove tops/debris from streams. Issues relating to the proper establishment of streamside management zones were the most prevalent BMP compliance issues noted during the scoring effort.

This overall decline in the establishment of critical forestry BMP structures on harvested sites across the state in one year is significant, but we expect this decline to continue unabated without a definitive and well-advertised increase in the number of BMP site inspections in the coming years. The establishment of BMP related work costs loggers both time and money, so, unless WV DOF based forestry BMP regulation is re-established in some meaningful way to encourage compliance, we project that BMP related site issues will continue to be a problem for the state. 
Non-Notified Timber Harvests

Efforts to quantify BMP compliance on non-notified harvested site inspection were inconclusive. Given inherent issues with the identification of these sites, as well as the small and closely distributed samples that were located during the study, no statistically significant sample could be obtained. However, during the process of the identification and inspection of the identified non-notified harvested sites, several important observations were made relative to non-notified sites.

For the small sample of researcher inspected non-notified harvests, only 40 percent of these sites passed a BMP compliance inspection and the overall BMP establishment score was 42 percent. Problems on these sites mirrored those for notified harvested sites in terms of most frequently missing BMP criteria such as water bars, streamside management buffers, and debris left in stream areas.

There are a variety of reasons a harvested site might be non-notified, beyond willful non-notification. Loggers may be moving from one harvest to another in close proximity to their original notified site and simply forget to file an additional notification. Loggers may also have clerical issues in filing their notifications. A site may well have proper forestry BMPs established, yet still be out of compliance with the LSCA simply because the logger forgot/failed to notify the WV DOF.

A strong correlation seems to exist between the layoffs at WV DOF and the issues identified here, relative to BMP compliance levels. However, some of these issues might be due to confusion among loggers in the state, since there is no longer any "hands-on" support and guidance from WV DOF personnel. Regardless, without 
some type of WV DOF led forestry BMP regulation, compliance will probably continue to be an issue.

\section{Limitations}

Certain limitations within this study should be noted. The pass/fail nature of the inspection process on harvested sites in this study was designed to mirror a typical WV DOF inspection. The nature of these inspections requires on-site visits by foresters to make professional decisions relative to the imminent risk of non-point source water pollution on a harvested site. This decision-making process uses the forester's best judgement to determine if a site passes or fail, based upon a holistic approach that considers factors such as relevant BMP criteria and site conditions such as slope, topography, and proximity to adjacent streams. This determination process is site specific, considering a wide range of factors, instead of a rigid system of specific and uniformly required criteria. The methods of this study mirror this process as closely as possible.

$\underline{\text { Conclusions }}$

Since the establishment of the Logging Sediment Control Act in 1992, the West Virginia Division of Forestry has a proven record of successfully enforcing the LSCA and providing a valuable service to loggers within West Virginia in terms of education, outreach, and corrective enforcement of forestry Best Management Practices for all timber harvesting activities within the state. Likewise, the proper establishment of forestry Best Management Practices on harvested sites throughout West Virginia has proven to greatly contribute to the sustainability of timber harvesting within the state. 
BMP compliance inspections have also helped to mitigate non-point source pollution in West Virginia's streams and watersheds. The LSCA and the services provided by the West Virginia Division of Forestry have been a success story of proper implementation and enforcement of scientific based forestry practices.

Unless the WV DOF again assumes the responsibility for BMP compliance and enforcement of LSCA regulations on harvested sites, one should expect continued declines in timber harvest notifications and BMP compliance on harvested sites. Furthermore, according to Merriam et al. (2017), current climate model predictions for watersheds within West Virginia predict an increase over time in stream discharge and flow, further exasperating levels of water discharge coming off harvested sites within the state. This will invariably lead to a greater occurrence of non-point source pollution (sedimentation) entering our forested streams and rivers and, quite probably, an associated decline in water quality. 


\section{Further Research}

One possible research topic that evolved through discussion of the study results involves the development of a non-point source stream pollution risk matrix, specifically constructed for individual harvested sites prior to the start of logging operations.

Table 4. Risk Matrix concept to predict the potential for non-point source stream pollution.

\begin{tabular}{|l|l|l|l|l|}
\hline Risk Level & \multicolumn{4}{|c|}{ Risk Element } \\
\hline & Average Slope & Perineal Streams & Acreage & Logger Citation History \\
\hline Low & $0-10$ & 0 & $<50$ & Excellent \\
\hline Med & $11-20$ & 1 & $<100$ & Good \\
\hline High & $20+$ & $2+$ & $<1000$ & Poor \\
\hline
\end{tabular}

Table 4 illustrates a conceptual risk matrix that can be generated using readily available sets of spatial data, stream hydrography, data elevation models, harvested area boundary, and land ownership. Using data elevation and stream hydrography data for the study area, a predictive model can be developed using zonal statistics as a table toolset. This toolset would categorically rank slope and stream presence from low to high risk levels, and define proximity of the site to sensitive streams. The resulting output helps to determine which sites planned for harvest are most at risk for non-point source pollution, and which areas are less likely to have issues.

The proposed risk matrix has the potential to help foresters prioritize BMP compliance by ranking the potential for non-point source pollution on harvested areas, allowing foresters to devote more attention to sites with greater sedimentation concerns 
and minimize the time spent managing harvest sites not likely to have sedimentation issues. By including historical performance data for the logging company and the logging system that will be used for the harvest, BMP foresters could more accurately predict potential stream pollution problems before they happen.

With fewer staff available to conduct BMP compliance inspections, greater reliance on technology and labor-saving approaches, like the proposed Risk Matrix model, will be necessary. Other options, like drone based inspections and a greater reliance on satellite and remotely sensed data for preliminary inspections, may also evolve to be standard tools available to state forestry professionals in the coming year, thereby reducing our reliance on "feet on the ground" BMP management in West Virginia. 


\section{Bibliography}

33 U.S.C. $\S 1251$ et seq. (1972). Federal Clean Water Act.

33 U.S.C. § 1329 (1987) Federal Clean Water Act Section 319.

Arthur, M.A. Coltharp, J.B. Brown, D. L. (1998). Effects of Best Management Practices on Streamwater Quality in Eastern Kentucky. Journal of American Water Resources Association 34(3): 481-495.

Aust, W.M. Shaffer, R.M. and Burger, J.A. (1996). Benefits and Costs of Forestry Best Management Practices in Virginia. Southern Journal of Applied Forestry. 20(1):23-29.

Blinn, C.R. Kilgore, M.A. (2001. August). Riparian Management Practices: A Summary of State Guidelines. Journal of Forestry-Washington 99(8):11-17.

Environmental Protection Agency. (2004). 2004 National Water Quality Inventory Report to Congress.

Kochendorfer, J. N. Edwards, P.J. Wood, F. (1997. December) Hydrological Impacts of Logging Appalachian Watershed Using West Virginia's Best Management Practices. Northern Journal of Applied Forestry. 14(4): 207-218.

Merriam E.R., Fernandez R., Petty J.T., Zegre N., (2017. Dec) Can Brook Trout Survive Climate Change in Large Rivers? If it Rains. Science of the Total Environment. Vol. 607:1225-1236. 
National Association of State Foresters. Map of Forestry Best Management Practices by State. Retrieved From http://www.stateforesters.org/action-issues-andpolicy/state-forestry-BMPs-map

Shepard, J. (2005). Water Quality Protection in Bioenergy Production: The US System of Forestry Best Management Practices. Biomass and Energy 30(4): 378-384.

Wang. J., McNeel, J., Goff, W. and Milauskas, S. (2007. May) Assessment of Compliance of Forestry Best Management Practices in West Virginia. Southern Journal of Applied Forestry. 31(2):60-65

West Virginia Division of Forestry. (2014). A Good Water Bar. [Photograph]. Retrieved from West Virginia Silvicultural Best Management Practices for Controlling Soil Erosion and Sedimentation from Logging Operations.

West Virginia Division of Forestry. (2014). Streamside Management Zone Example. [Photograph]. Retrieved from West Virginia Silvicultural Best Management Practices for Controlling Soil Erosion and Sedimentation from Logging Operations.

West Virginia Division of Forestry. (2014). West Virginia Silvicultural Best Management Practices for Controlling Soil Erosion and Sedimentation from Logging Operations.

West Virginia Legislature, West Virginia Code Chapter 19. 1992. Agriculture Article 1B. Sediment Control During Commercial Timber Harvesting Operations. Logging Sediment Control Act. 
